\title{
TSH stimulates leptin secretion by a direct effect on adipocytes
}

\author{
C Menendez ${ }^{1}$, R Baldelli ${ }^{1,3}$, J P Camiña ${ }^{1}$, B Escudero ${ }^{1}$, R Peino ${ }^{1}$, \\ C Dieguez ${ }^{2}$ and F F Casanueva ${ }^{1}$ \\ ${ }^{1}$ Department of Medicine, Research Area, Molecular Endocrinology Laboratory, Complejo Hospitalario Universitario de Santiago (CHUS), University of \\ Santiago de Compostela, Santiago de Compostela E-15782, Spain \\ ${ }^{2}$ Department of Physiology, University of Santiago de Compostela, Santiago de Compostela E-15782, Spain \\ ${ }^{3}$ Endocrinology Service, Regina Elena Cancer Institute, Rome, Italy \\ (Requests for offprints should be addressed to F F Casanueva, PO Box 563, Santiago de Compostela E-15782, Spain; Email: endocrine@usc.es)
}

\begin{abstract}
Leptin is a circulating hormone secreted by adipose tissue which acts as a signal to the central nervous system where it regulates energy homeostasis and neuroendocrine processes. Although leptin modulates the secretion of several pituitary hormones, no information is available regarding a direct action of pituitary products on leptin release. However, it has been pointed out that leptin and TSH have a coordinated pulsatility in plasma. In order to test a direct action of TSH on in vitro leptin secretion, a systematic study of organ cultures of human omental adipose tissue
\end{abstract}

was performed in samples obtained at surgery from 34 patients of both sexes during elective abdominal surgery. TSH powerfully stimulated leptin secretion by human adipose tissue in vitro. In contrast, prolactin, ACTH, FSH and $\mathrm{LH}$ were devoid of action. These results suggest that leptin and the thyroid axis maintain a complex and dual relationship and open the possibility that plasmatic changes in TSH may contribute to the regulation of leptin pulses. Journal of Endocrinology (2003) 176, 7-12

\section{Introduction}

Leptin, the adipocyte-derived hormone, participates in the regulation of energy homeostasis by providing the central nervous system with information on the state of the adipose tissue reserves (Zhang et al. 1994, Casanueva \& Dieguez 1999). In turn, leptin receptors at the hypothalamus activate the efferent loop leading to control of food intake and energy expenditure as a form of regulating energy stores (Campfield et al. 1995, Ahima et al. 1996, Casanueva \& Dieguez 1999). In the currently accepted paradigm, leptin should be viewed as a message that is mostly operative when plasma levels are reduced due to shortage of food; thus, plasma leptin reduction activates the complex neuroendocrine and behavioural response to fasting (Ahima et al. 1996). In addition, leptin modulates the function of several endocrine axes, such as the somatotroph (Carro et al. 1999, 2000), gonadal (Mantzoros 2000, Caprio et al. 2001), corticotroph (Heiman et al. 1997) and thyroid (Legradi et al. 1997, 1998) axes. Through leptin, the nutritional situation of a given individual is communicated to and modulates the other endocrine activities (Casanueva \& Dieguez 1999).

One of the most surprising points of leptin physiology is its pulsatility in plasma (Licinio et al. 1997). In fact, it is not easily understandable how a hormone produced by millions of adipocytes widely distributed throughout the body may be synchronized to show pulses. In a comprehensive study Mantzoros et al.( 2001) have shown that leptin and plasma thyrotrophin (TSH) levels are both highly organized and pulsatile, with similar circadian rhythms, and using a cosinor analysis they showed near superimposable peak values. This, and other studies analysing leptin and the thyroid axes, strongly suggest that leptin regulates, at least partially, TSH secretion in man (Seoane et al. 2000).

Although leptin modulation of the thyroid axis is well accepted, the action of the thyroid axis components on leptin secretion has not been fully characterized. Thyroid hormones in vitro (Menendez et al. 2001) or in vivo (Corbetta et al. 1997, Sreenan et al. 1997, Valcavi et al. 1997) are not particularly relevant to the secretion of leptin in man. However, the action of TSH over leptin secretion has not, to our knowledge, been assessed. On theoretical grounds at least, such a control is feasible, as we are now well aware that plasma leptin levels do not just have a stoichiometric relationship with fat mass. On the contrary, leptin levels reflect fat mass plus the action of several circulating hormones and factors, which directly operate on the adipocytes releasing leptin (Considine et al. 1997, Casabiell et al. 1998, Menendez et al. 2000).

In the present work we have taken advantage of a well-characterized and validated organ culture model of human adipose tissue (Casabiell et al. 1998, Piñeiro et al. 1998), to test in vitro the action of TSH over leptin 
secretion, taking as an internal control other pituitary hormones. The working hypothesis was that the connection between the thyroid axis and leptin may well be exerted in part through TSH.

\section{Materials and Methods}

Omental adipose tissue was obtained from 34 patients during elective abdominal surgery. The tissue donor group was composed of 17 females (age $66 \pm 4$ (S.E.) years; body mass index (BMI) 25.44 $\pm 1 \cdot 15$ ) and 17 males (age $65 \pm 4$ years; BMI 28.45 $\pm 1 \cdot 57)$. Patients were taking no drugs or antibiotics and the presence of malignancy was an exclusion criteria. The study was approved by the Hospital Ethical Committee, and each participating subject provided informed consent. Excised adipose tissue was immediately transported to the laboratory in ice-cold Krebs-Ringer-Hepes buffer $(\mathrm{NaCl}, 125 \mathrm{mM}$; $\mathrm{KCl}$, $5 \mathrm{mM} ; \mathrm{MgSO}_{4}, 1.2 \mathrm{mM} ; \mathrm{CaCl}_{2}, 2 \mathrm{mM} ; \mathrm{KH}_{2} \mathrm{PO}_{4}$, $1.2 \mathrm{mM}$; glucose, $6 \mathrm{mM}$; Hepes, $25 \mathrm{mM}$; pH 7.4). After removal of blood vessels and connective tissue, adipose tissue was washed with sterile Krebs-Ringer-Hepes and cut into small pieces with sharp scissors. Tissue fragments were placed in six-well dishes (300-400 mg adipose tissue/well) containing $2.5 \mathrm{ml}$ Dulbecco's modified Eagle's medium plus $0.5 \%$ fetal calf serum, supplemented with penicillin $(100 \mathrm{U} / \mathrm{ml})$ and streptomycin sulphate $(100 \mu \mathrm{g} / \mathrm{ml})$. After a preincubation period of $1 \mathrm{~h}$ at $37{ }^{\circ} \mathrm{C}$ under a humidified atmosphere of $95 \%$ air $-5 \%$ $\mathrm{CO}_{2}$, the medium was aspirated and $2.5 \mathrm{ml}$ fresh medium were dispensed into each well. Culture medium was then collected every $24 \mathrm{~h}$ and replaced with fresh medium, again with or without stimuli, to obtain the $24 \mathrm{~h}$ secretion and the cumulative secretion until $48 \mathrm{~h}$. The adipose tissue of each donor was incubated in triplicate for each tested variable (either untreated or treated samples), either hormone or dose, and the final value of each individual was the pooled value.

In order to evaluate the possible effect of the pituitary hormones on in vitro leptin secretion, prolactin (PRL), adrenocorticotrophin (ACTH), follicle-stimulating hormone (FSH), luteinizing hormone (LH) and TSH were tested at different doses $\left(10^{-13}, 10^{-11}, 10^{-9}, 10^{-7} \mathrm{M}\right)$ with respect to control samples with the appropriate vehicle. Although in pilot experiments it was demonstrated that this organ culture was viable for more than 7 days, the changes elicited by pituitary hormones were observed only in the first 2 days, followed by a plateau in leptin release thereafter. For such reasons leptin values were analysed in the first $48 \mathrm{~h}$. Histological, toluidine blue staining, and biochemical analysis, lactate dehydrogenase (LDH) release to the medium, showed that there was no tissue damage during culture. Samples were stored at $-20{ }^{\circ} \mathrm{C}$ until leptin assay.

PRL was obtained from the US National Institute of Diabetes, Digestive and Kidney Diseases National
Hormone and Pituitary Program (Bethesda, MD, USA). The others compounds and reagents were obtained from Sigma.

\section{Leptin assay}

Leptin levels were measured by RIA using commercial kits (Human Leptin RIA; Linco, St Charles, MO, USA). The limit of sensitivity was $0.5 \mathrm{ng} / \mathrm{ml}$, the intra-assay coefficient of variation was $8 \cdot 3 \%$ and the interassay coefficient of variation was $6 \cdot 2 \%$.

\section{Statistical analysis}

Leptin secretion is expressed as the total amount of leptin secreted into the well by a given sample (in $\mathrm{ng} / \mathrm{ml}$ ) with respect to total volume and divided by the amount of fat tissue in grams, i.e. ng leptin/g tissue. Unless otherwise specified, all data are presented as means \pm S.E. The $t$-test for paired data was used to evaluate leptin secretion over control samples, and $P<0.05$ was considered significant. Statistical analyses were made using Statview 5 software for Windows (SAS Institute Inc., Cary, NC, USA, 1999).

\section{Results}

Spontaneous leptin secretion by omental adipose tissue to the incubation medium was progressive in control samples $(n=34)$ of both sexes from 0 to $48 \mathrm{~h}$ (data not shown). Histological and biochemical analysis showed that there was no tissue damage throughout the incubation period, tested by toluidine blue staining and LDH release to the medium, in accord with previous studies (Casabiell et al. 1998, Piñeiro et al. 1998, 1999, Menendez et al. 2000, 2001, Peino et al. 2000). As both treated and untreated samples exhibited significant leptin release in the first $48 \mathrm{~h}$, plateauing thereafter, it was decided to analyse only the first $48 \mathrm{~h}$ period. As no gender-based differences were observed in any test, individual values were pooled.

A clear-cut stimulation of leptin secretion was observed when the adipose tissue fragments from seven donors $(n=7)$ were incubated in the presence of TSH $\left(10^{-13}\right.$, $\left.10^{-11}, 10^{-9} \mathrm{M}\right)$; in particular, the leptin secretion rate was potently stimulated at the $48 \mathrm{~h}$ period at the concentration of $10^{-9} \quad(P<0 \cdot 0005), 10^{-11} \quad(P<0 \cdot 05)$ and $10^{-13} \mathrm{M}(P<0 \cdot 005)$ (Fig. 1).

When the adipose tissue fragments from eight donors were incubated in the presence of PRL $\left(10^{-11}, 10^{-9}\right.$, $\left.10^{-7} \mathrm{M}\right)$, a slight inhibition in the leptin secretion rate was observed at $10^{-11} \mathrm{M}(P<0 \cdot 05)$ but not at other doses. The incubation with ACTH $\left(10^{-11}, 10^{-9}, 10^{-7} \mathrm{M}\right)$ $(n=8)$, FSH $\left(10^{-13}, 10^{-11}, 10^{-9} \mathrm{M}\right)(n=9)$ and LH $\left(10^{-13}, 10^{-11}, 10^{-9} \mathrm{M}\right)(n=8)$ did not induce significant 


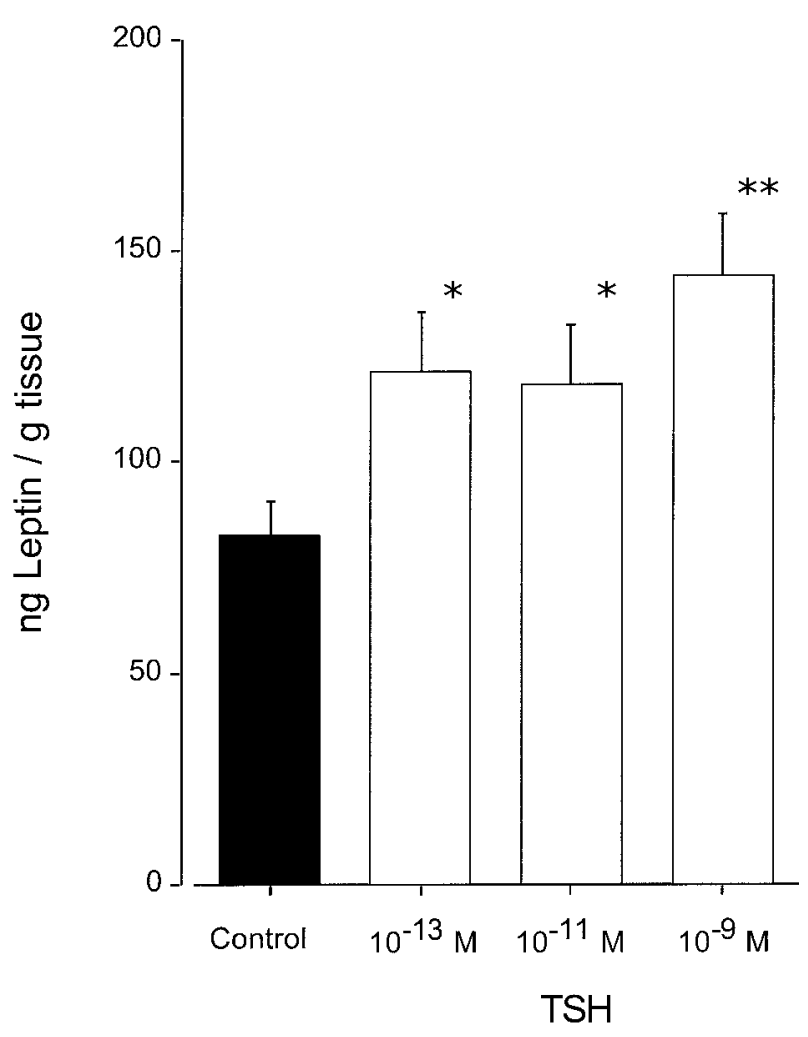

Figure 1 Effect of TSH administration on in vitro leptin secretion by human omental adipose tissue cultures $(n=7)$. Means \pm S.E. ${ }^{*} P<0.05$ vs control, ${ }^{* *} P<0 \cdot 005$ vs control.

changes in leptin secretion rates from adipose tissue culture (Fig. 2).

\section{Discussion}

In the present work it has been unambiguously demonstrated, and to the best of our knowledge for the first time, that TSH releases leptin by a direct action at the adipocytes in human adipose tissue. This result fits with the presence of TSH receptors in adipose tissue, frequently reported, but until now devoid of physiological action (Sorisky et al. 2000). In support of the specificity of the action observed, other pituitary hormones, such as PRL and ACTH, were devoid of action, and the same lack of direct activity was observed for pituitary hormones with similar structures to TSH, such as LH and FSH. These data supply information for understanding the variables controlling leptin levels in plasma and support the view that net adipose mass is the main determinant of these levels, but that in addition the action of steroid (Casabiell et al. 1998, Piñeiro et al. 1999) and non-steroid hormones (Menendez et al. 2001) plus other non-hormonal factors (Piñeiro et al. 1998, Peino et al. 2000), determine the final level of leptin release into plasma. The organ culture model used in this work shows a considerable advantage, such as simplicity and convenience of manipulation, facts highly relevant when dealing with adipose tissue. Dispersed adipose tissue culture presents the disadvantage of disruption of the structural framework plus elimination of the small-diameter adipocytes. In addition, isolated adipocytes float, making cultures cumbersome. The present model has been employed successfully by us (Casabiell et al. 1998, Piñeiro et al. 1998, 1999, Menendez et al. 2000, 2001, Peino et al. 2000) and other groups (Gottschling-Zeller et al. 1999, Williams et al. 2000, Tomlinson et al. 2001), and strict control studies showed no damage up to 7 days of incubation. Although leptin release should be detected after just a few hours of incubation, the amount released by the small pieces of tissue employed is very small. The system of collecting media every $24 \mathrm{~h}$ allows assay of the cumulative secretion of leptin. As both spontaneous and stimulated leptin secretion was observed in the first $48 \mathrm{~h}$, released leptin being at a plateau thereafter, values were calculated in the first $48 \mathrm{~h}$ period. That situation is different from the leptin release elicited by nuclear hormones, such as glucocorticoids, that may be observed over several days, but it is in keeping with the prompt action of protein hormones operating on surface receptors.

The relationship between the thyrotrophin-releasing hormone (TRH)-TSH-thyroid hormone axis and leptin is complex but meaningful. In fact, it is a well known fact that food deprivation, a condition associated with low plasma leptin concentrations, leads to low thyroid hormone levels plus decreased synthesis of TRH at hypothalamic structures and decreased TSH synthesis at the pituitary (Orban et al. 1998). Acting as an afferent signal to the brain, leptin administration to food-deprived animals is able to restore the decreased proTRH mRNA in the neurons of the paraventricular nucleus (Legradi et al. 1997, 1998). This increase in TRH may explain why leptin administration raises TSH levels, and normalizes the reduced thyroid hormone levels in euthyroid fooddeprived rats (Ahima et al. 1996, Legradi et al. 1997). However, studies in humans (Rosenbaum et al. 2000, 2002) have shown that alteration in body weight may reduce leptin, and thyroid hormone, without altering TSH values, while other reports have described a leptin action on TSH release (Seoane et al. 2000). As the reduction in thermogenesis, due to a reduction in thyroid hormone levels, is one of the most remarkable adaptive responses to fasting, it is easy to imagine that low energy intake leads to reduced leptin levels and that this reduction acting at the level of the hypothalamus induces a step-wise reduction in $\mathrm{TRH}$, then in TSH, and finally in thyroid hormones, with the ensuing final adjustment of the general metabolism of the individual to the new situation. In support of this hypothetical mechanism, some patients with leptin deficiency due to genetic mutations exhibit hypothalamic hypothyroidism (Clement et al. 1998). The efferent loop of 


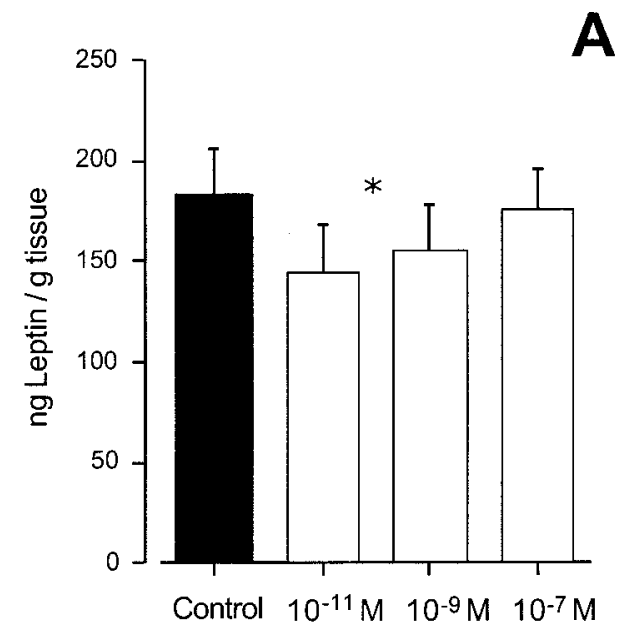

PRL

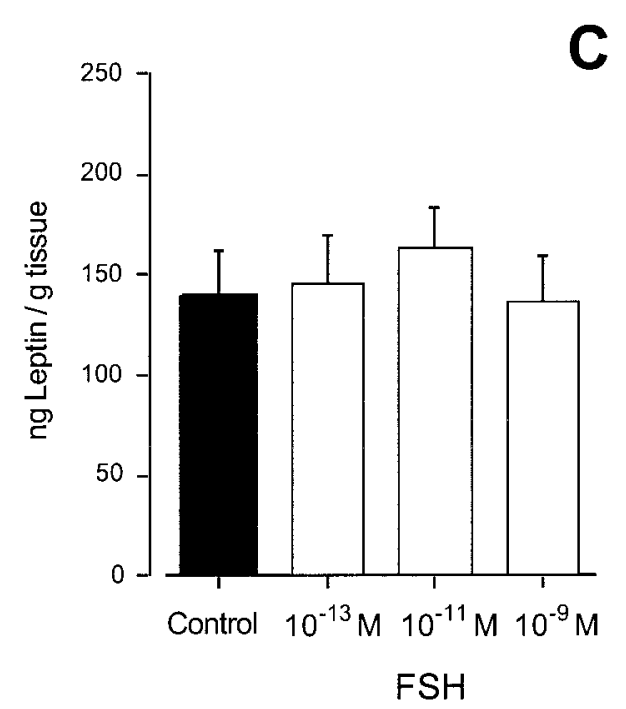

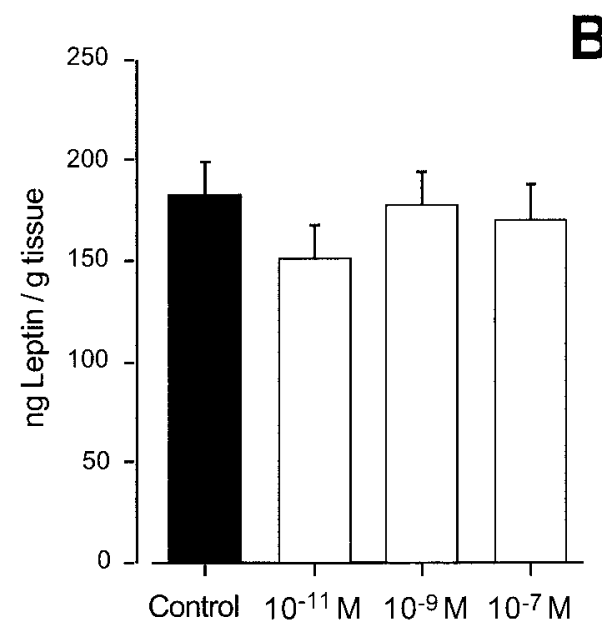

$\mathrm{ACTH}$

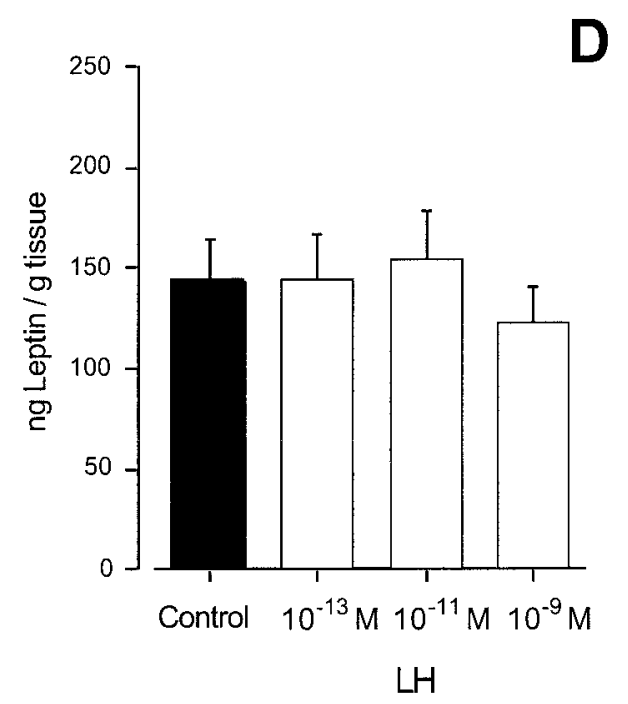

Figure 2 Effect of (A) PRL $(n=8)$, (B) ACTH $(n=8)$, (C) FSH $(n=9)$ and (D) $\mathrm{LH}(n=8)$ administration on in vitro leptin secretion by human omental adipose tissue cultures. Means \pm S.E. ${ }^{*} P<0.05$ vs control.

the leptin-thyroid axis relationship has also been studied, in part supported by the known alteration in body weight that occurs in thyroid diseases. However, both in experimental animals (Escobar-Morreale et al. 1997, Fain et al. 1997), and in humans (Corbetta et al. 1997, Sreenan et al. 1997, Valcavi et al. 1997, Leonhardt et al. 1998, Pinkney et al. 1998, Yoshida et al. 1998), no data have demonstrated in a definitive way that thyroid hormones may change circulating leptin levels, and the scarce leptin changes observed were explained by parallel alterations in body weight of the subjects under observation. Supporting that lack of action of thyroid hormones, studies with human adipose tissue showed no changes in leptin release when incubated with significant concentrations of thyroid hormones in vitro (Menendez et al. 2001). The present report of a direct action of TSH on leptin secretion, exerted directly at the adipocyte level in human tissue, adds a new dimension to the complex relationship between the two points of the system, although it must be remembered that other factors continuously operate superimposed on the TSH actions in order to modulate the final levels of leptin in plasma.

The TSH-mediated leptin release may be of interest when trying to understand the leptin pulsatility in plasma. Until now no acceptable explanation has been provided for the unexpected situation of pulsatility of a hormone produced by millions of adipocytes dispersed throughout the body. Obviously, such a disperse production would 
need a synchronizer or a pace-maker coming from outside the adipose tissue. One candidate could be the sympathetic nervous system that powerfully interacts with the adipose tissue, but other contributing factors should exist, and one of them may well be TSH, which, as opposed to TRH, circulates in significant concentrations and exhibits strong pulsatility. In fact, Mantzoros et al. (2001) have shown in a systematically and mathematically validated analysis that TSH and leptin exhibit coordinated pulsatility. As the amount of leptin released in the tissue culture model is low, the cumulative amount released was analysed at $48 \mathrm{~h}$, thus it was not possible to test if short-time (minutes) TSH pulses may elicit short-term leptin discharges. Although the results given in the present study do not demonstrate that TSH participates even minimally in leptin pulsatility, such an action is possible.

In order to analyse whether the actions of TSH were specific or, on the contrary, shared by other pituitary hormones, some structurally related and unrelated pituitary hormones were also studied, with negative results. Changes in PRL levels have been associated with alterations in leptin levels suggesting a positive relationship (Gualillo et al. 1999), a fact that may well explain the known association of hyperprolactinaemia and obesity (Nunes et al. 1980, Greenman et al. 1998). However, there is no support either in experimental animals (Gualillo et al. 1999) or in the present work, for a direct PRL action on the adipocyte production of leptin. Similarly, hypercorticoid states are associated with enhanced leptin levels (Leal-Cerro et al. 1996, Masuzaki et al. 1997) and glucocorticoids are potent inducers of leptin synthesis and secretion at the adipose tissue level (Considine et al. 1997, Casabiell et al. 1998), but no data link ACTH with a direct action on the adipocyte and the present results also discard that mechanism. Finally, while the action of leptin over gonadotrophin-releasing hormone secretion by the hypothalamus is well supported ( $\mathrm{Yu}$ et al. 1997, Carro et al. 1999, Magni et al. 1999), no direct interaction between LH or FSH and leptin has been reported previously or observed in this work. All these negative results with hormones, other than TSH, lend further support to the specificity of the TSH action and its relevance. As a final observation, no gender-based differences were observed in the leptin secreted by the adipose tissue fragments when exposed to the pituitary hormones. That is a relevant observation when considering that adrenal and gonadal steroids show a marked difference in their action upon in vitro leptin secretion depending on the sex of the tissue donor (Casabiell et al. 1998, Piñeiro et al. 1999). These results suggest that, contrary to hormone actions on nuclear receptors, hormones operating through surface receptors have no gender-based specificity.

In conclusion, TSH significantly stimulates leptin secretion by human adipose tissue in vitro, suggesting a new mechanism in the interrelationship between the adipose tissue organ and the thyroid axis.

\section{Acknowledgements}

This work was supported by grants from Fondo de Investigación Sanitaria, Spanish Ministry of Health and the Xunta de Galicia and by grant 009906153187 from MURST (40\%, Rome, Italy) and CISD (Rome, Italy). Jesus P Camina is a recipient of a Research Contract from the Spanish Ministry of Health, Fondo de Investigación Sanitaria, Institute of Health Carlos III at Research Area of the CHUS.

\section{References}

Ahima RS, Prabakaran D, Mantzoros C, Qu D, Lowell B, Maratos Flier E \& Flier JS 1996 Role of leptin in the neuroendocrine response to fasting. Nature 382 250-252.

Campfield L, Smith F, Guisez Y, Devos R \& Burn P 1995 Recombinant mouse $\mathrm{OB}$ protein: evidence for a peripheral signal linking adiposity and central neural networks. Science 269 546-549.

Caprio M, Fabbrini E, Isidori AM, Aversa A \& Fabbri A 2001 Leptin in reproduction. Trends in Endocrinology and Metabolism 12 65-72.

Carro E, Senaris RM, Seoane LM, Frohman LA, Arimura A, Casanueva FF \& Dieguez C 1999 Role of growth hormone (GH)releasing hormone and somatostatin on leptin-induced $\mathrm{GH}$ secretion. Neuroendocrinology 69 3-10.

Carro E, Seoane LM, Senaris R, Casanueva FF \& Dieguez C 2000 Leptin increases in vivo $\mathrm{GH}$ responses to $\mathrm{GHRH}$ and $\mathrm{GH}$-releasing peptide-6 in food-deprived rats. European Journal of Endocrinology $14266-70$.

Casabiell X, Pineiro V, Peino R, Lage M, Camina J, Gallego R, Vallejo LG, Dieguez C \& Casanueva FF 1998 Gender differences in both spontaneous and stimulated leptin secretion by human omental adipose tissue in vitro: dexamethasone and estradiol stimulate leptin release in women, but not in men. Journal of Clinical Endocrinology and Metabolism 83 2149-2155.

Casanueva FF \& Dieguez C 1999 Neuroendocrine regulation and actions of leptin. Frontiers in Neuroendocrinology 20 317-363.

Clement K, Vaisse C, Lahlou N, Cabrol S, Pelloux V, Cassuto D, Gourmelen M, Dina C, Chambaz J, Lacorte JM et al. 1998 A mutation in the human leptin receptor gene causes obesity and pituitary dysfunction. Nature 392 398-401.

Considine RV, Nyce MR, Kolaczynski JW, Zhang PL, Ohannesian JP, Moore JH Jr, Fox JW \& Caro JF 1997 Dexamethasone stimulates leptin release from human adipocytes: unexpected inhibition by insulin. Journal of Cellular Biochemistry 65 254-258.

Corbetta S, Englaro P, Giambona S, Persani L, Blum WF \& Beck Peccoz P 1997 Lack of effects of circulating thyroid hormone levels on serum leptin concentrations. European Journal of Endocrinology 137 659-663.

Escobar-Morreale HF, Escobar del Rey F \& Morreale de Escobar G 1997 Thyroid hormones influence serum leptin concentrations in the rat. Endocrinology 138 4485-4488.

Fain JN, Coronel EC, Beauchamp MJ \& Bahouth SW 1997 Expression of leptin and beta 3 -adrenergic receptors in rat adipose tissue in altered thyroid states. Biochemical Journal 15 145-150.

Gottschling-Zeller H, Birgel M, Scriba D, Blum WF \& Hauner H 1999 Depot-specific release of leptin from subcutaneous and omental adipocytes in suspension culture: effect of tumor necrosis factor-alpha and transforming growth factor-beta 1. European Journal of Endocrinology 141 436-442.

Greenman Y, Tordjman K \& Stern N 1998 Increased body weight associated with prolactin secreting pituitary adenomas: weight loss with normalization of prolactin levels. Clinical Endocrinology 48 547-553. 
Gualillo O, Lago F, Garcia M, Menendez C, Senaris R, Casanueva FF \& Dieguez C 1999 Prolactin stimulates leptin secretion by rat white adipose tissue. Endocrinology 140 5149-5153.

Heiman ML, Ahima RS, Craft LS, Schoner B, Stephens TW \& Flier JS 1997 Leptin inhibition of the hypothalamic-pituitary-adrenal axis response to stress. Endocrinology 138 3859-3863.

Leal-Cerro A, Considine RV, Peino R, Venegas E, Astorga R, Casanueva FF \& Dieguez C 1996 Serum immunoreactive-leptin levels are increased in patients with Cushing's syndrome. Hormone and Metabolic Research 28 711-713.

Legradi G, Emerson CH, Ahima RS, Flier JS \& Lechan RM 1997 Leptin prevents fasting-induced suppression of prothyrotropinreleasing hormone messenger ribonucleic acid in neurons of the hypothalamic paraventricular nucleus. Endocrinology 138 2569-2576.

Legradi G, Emerson CH, Ahima RS, Rand WM, Flier JS \& Lechan RM 1998 Arcuate nucleus ablation prevents fasting-induced suppression of ProTRH mRNA in the hypothalamic paraventricular nucleus. Neuroendocrinology 68 89-97.

Leonhardt U, Ritzel U, Schafer G, Becker W \& Ramadori G 1998 Serum leptin levels in hypo- and hyperthyroidism. Journal of Endocrinology 157 75-79.

Licinio J, Mantzoros C, Negrao AB, Cizza G, Wong ML, Bongiorno PB, Chrousos GP, Karp B, Allen C, Flier JS et al. 1997 Human leptin levels are pulsatile and inversely related to pituitary-adrenal function. Nature Medicine 3 575-579.

Magni P, Vettor R, Pagano C, Calcagno A, Beretta E, Messi E, Zanisi M, Martini L \& Motta M 1999 Expression of a leptin receptor in immortalized gonadotropin-releasing hormone-secreting neurons. Endocrinology 140 1581-1585.

Mantzoros CS 2000 Role of leptin in reproduction. Annals of the New York Academy of Sciences $\mathbf{9 0 0}$ 174-183.

Mantzoros CS, Ozata M, Negrao AB, Suchard MA, Ziotopoulou M, Caglayan S, Elashoff RM, Cogswell RJ, Negro P, Liberty V et al. 2001 Synchronicity of frequently sampled thyrotropin (TSH) and leptin concentrations in healthy adults and leptin-deficient subjects: evidence for possible partial TSH regulation by leptin in humans. Journal of Clinical Endocrinology and Metabolism 86 3284-3291.

Masuzaki H, Ogawa Y, Hosoda K, Miyawaki T, Hanaoka I, Hiraoka J, Yasuno A, Nishimura H, Ypshimasa Y, Nishi S et al. 1997 Glucocorticoid regulation of leptin synthesis and secretion in humans: elevated plasma leptin concentrations in Cushing's syndrome. Journal of Clinical Endocrinology and Metabolism 82 2542-2547.

Menendez C, Baldelli R, Lage M, Casabiell X, Piñeiro V, Solar J, Dieguez C \& Casanueva FF 2000 The in vitro secretion of human leptin is gender-dependent but independent of the body mass index of the donors. European Journal of Endocrinology 143 711-714.

Menendez C, Lage Mi, Peino R, Baldelli R, Concheiro P, Dieguez C \& Casanueva FF 2001 Retinoic acid and vitamin D3 powerfully inhibit in vitro leptin secretion by human adipose tissue. Journal of Endocrinology 170 425-431.

Nunes M, Sobrinho L, Calhoz-Jorge C, Santos M, Mauricio M \& Sousa M 1980 Psychosomatic factors in patient with hyperprolactinemia and/or galactorhea. Obstetrics and Gynecology 55 591-595.

Orban Z, Bornstein SR \& Chrousos GP 1998 The interaction between leptin and the hypothalamic-pituitary-thyroid axis. Hormone and Metabolic Research 30 231-235.

Peino R, Pineiro V, Gualillo O, Menendez C, Brenlla J, Casabiell X, Dieguez C \& Casanueva FF 2000 Cold exposure inhibits leptin secretion in vitro by a direct and non-specific action on adipose tissue. European Journal of Endocrinology 142 195-199.
Piñeiro V, Casabiell X, Peino R, Garcia-Vallejo L, Dieguez C \& Casanueva FF 1998 PMA inhibits both spontaneous and glucocorticoid-mediated leptin secretion by human omental adipose tissue explants in vitro. Biochemical and Biophysical Research Communications 252 345-347.

Piñeiro V, Casabiell X, Peino R, Lage M, Camina JP, Menendez C, Baltar J, Dieguez C \& Casanueva FF 1999 Dihydrotestosterone, stanozolol, androstenedione and dehydroepiandrosterone sulphate inhibit leptin secretion in female but not in male samples of omental adipose tissue in vitro: lack of effect of testosterone. Journal of Endocrinology 160 425-432.

Pinkney JH, Goodrick SJ, Katz J, Johnson A, Lightman SC, Coppack SW \& Mohamed-Ali V 1998 Leptin and the pituitary-thyroid axis: a comparative study in lean, obese, hypothyroid and hyperthyroid subjects. Clinical Endocrinology 49 583-588.

Rosenbaum M, Hirsch J, Murphy E \& Leibel RL 2000 Effects of changes in body weight on carbohydrate metabolism, catecholamine excretion, and thyroid function. American Journal of Clinical Nutrition 71 1421-1432.

Rosenbaum M, Murphy EM, Heymsfield SB, Matthews DE \& Leibel RL 2002 Low dose leptin administration reverses effects of sustained weight-reduction on energy expenditure and circulating concentrations of thyroid hormones. Journal of Clinical Endocrinology and Metabolism 87 2391-2394.

Seoane LM, Carro E, Tovar S, Casanueva FF \& Dieguez C 2000 Regulation of in vivo TSH secretion by leptin. Regulatory Peptides 92 $25-29$.

Sorisky A, Bell A \& Gagnon A 2000 TSH receptor in adipose cells. Hormone and Metabolic Research 32 468-474.

Sreenan S, Caro JF \& Refetoff S 1997 Thyroid dysfunction is not associated with alterations in serum leptin levels. Thyroid 7 407-409.

Tomlinson JW, Moore J, Cooper MS, Bujalska I, Shahmanesh M, Burt C, Strain A, Hewison M \& Stewart PM 2001 Regulation of expression of 11 beta-hydroxysteroid dehydrogenase type 1 in adipose tissue: tissue-specific induction by cytokines. Endocrinology 142 1982-1989.

Valcavi R, Zini M, Peino R, Casanueva F \& Dieguez C 1997 Influence of thyroid status on serum immunoreactive leptin levels. Journal of Clinical Endocrinology and Metabolism 82 1632-1634.

Williams LB, Fawcett RL, Waechter AS, Zhang P, Kogon BE, Jones R, Inman M, Huse J \& Considine RV 2000 Leptin production in adipocytes from morbidly obese subjects: stimulation by dexamethasone, inhibition with troglitazone, and influence of gender. Journal of Clinical Endocrinology and Metabolism $\mathbf{8 5}$ 2678-2684.

Yoshida T, Momotani N, Hayashi M, Monkawa T, Ito K \& Saruta T 1998 Serum leptin concentrations in patients with thyroid disorders. Clinical Endocrinology 48 299-302.

Yu WH, Kimura M, Walczewska A, Karanth S \& McCann SM 1997 Role of leptin in hypothalamic-pituitary function. PNAS $\mathbf{9 4}$ 1023-1028.

Zhang Y, Proenca R, Maffei M, Barone M, Leopold L \& Friedman JM 1994 Positional cloning of the mouse obese gene its human homologue. Nature 372 425-432.

Received 11 September 2002

Accepted 17 September 2002 